\title{
Identity Politics, Citizenship and the 2010 Post-Election Conflict in Côte d'Ivoire
}

\author{
Denis Adesina Daniel1,2*, David Uchena Enweremadu² \\ ${ }^{1}$ Department of Board Affairs and Proceedings (PSEG. 1), African Development Bank Group, Abidjan, Côte d'Ivoire \\ ${ }^{2}$ Faculty of Social Sciences, Department of Political Science, University of Ibadan, Ibadan, Nigeria \\ Email: *ddaniel6392@stu.ui.edu.ng, *danieldenis741@yahoo.fr, uchennadave@yahoo.com
}

How to cite this paper: Daniel, D. A., \& Enweremadu, D. U. (2020). Identity Politics, Citizenship and the 2010 Post-Election Conflict in Côte d'Ivoire. Open Journal of Political Science, 10, 213-233.

https://doi.org/10.4236/ojps.2020.102015

Received: January 16, 2020

Accepted: March 17, 2020

Published: March 20, 2020

Copyright $\odot 2020$ by author(s) and Scientific Research Publishing Inc. This work is licensed under the Creative Commons Attribution International License (CC BY 4.0).

http://creativecommons.org/licenses/by/4.0/

\begin{abstract}
In 2010, Côte d'Ivoire witnessed a very devastating and unprecedented postelection conflict. The conflict resulted in both internal and external impact that over the years continue to affect the pace of development in the nation. This study aimed to investigate the causes and main drivers of the post-electoral crisis in Côte d'Ivoire in 2010. The study used expository research design adopting in-depth interviews to collect primary data and contextual approach to extract data from briefings from the crisis; UN, EU and international election observation reports and published information in press materials and peer-reviewed journals. The interviews were conducted through cluster sampling method with Election observers, ECOWAS Representation in Côte d'Ivoire, Staff of Abidjan Political Research Center "Centre de Recherche Politique d'Abidjan (CRPA)", National and International Civil Society, Political Experts, Conflict Experts, Political Scientists and Lecturers in the field. Structural descriptive and expository methods were used to analyse and present findings based on the Marxist and Liberal Structural theories of conflict. The study found out that the 2010 electoral conflict was caused by political flaws due to unclear policies and weak electoral institutions that allowed political interruption and manipulation. Furthermore, national identity was the main driver used by political actors to instrumentalize the conflict to make it seem like a civil war. Illiteracy, tribalism and religion were sensitive areas used to break social cohesion under the big umbrella of national identity. The concept of citizenship should be re-conceptualized and made clear in the constitution to prevent re-occurrence of post-election conflict in the coming years like 2020 .
\end{abstract}

\section{Keywords}

Post-Election Conflict, National Identity, Political Instrumentalization, Côte d'Ivoire 


\section{Introduction}

One characteristic feature of civil war in West Africa is the propensity to spread beyond national borders. In other words, civil wars in West Africa are never domesticated; they are often internationalized either by way of active external participation in the conflict or the impact of war being felt by neighbouring countries. Accordingly, the neighbouring effects of these wars often lead to or attract international response to such conflicts. The cause of conflict especially in West Africa has been reported mainly from struggle for political power (IPI, 2011; Salehyan and Linebarger, 2013; Annan, 2014). However, the spread of the conflict mostly borders on issues that affect society such as poverty, marginalization, corruption, human right violations, small arms and weapons proliferation, religion amongst others (Annan, 2014). The Republic of Côte d'Ivoire was once one of the stable and increasing developmental and prosperous ${ }^{1}$ countries in the West Africa region became instable after the failed coup attempt in 2002 (Gberie and Addo, 2004). A complicated civil war quickly followed the failed coup attempt due to the numerous violence that resulted.

National identity in sub-Saharan Africa had been a challenge since the colonial era due to the tie of citizens to different ethnic groups that has withstood ones especially, the use of one local language to represent a nation (Vogel, 1991). Africa was grouped based on ethnicity and culture. The division of the African continents by colonial masters ${ }^{2}$ was the beginning of identity crisis since people of the same groups were now divided into different countries (Konate, 2004). It was not surprising to see ethnic groups in Burkina Faso migrate to North of Côte d'Ivoire where a part of their ethnicity was separated to live by country or "colonial demarcation". This raises the question of who is a national or citizen of a nation? Before the colonization of Côte d'Ivoire, and later independence in 1960, the country spread based on the four main ethnic groups, namely; Mandé, Gour, Krou and Kwa (Konate, 2014). The four groups were also located in neighbouring countries. Therefore, the ideology of creating a national identity based on colonial demarcation of land area to form countries has resulted in many conflict instrumentalized by politicians due to their knowledge of how people value their route or origin and culture ${ }^{3}$.

\section{Theoretical Framework}

The two main theories of conflicts that extensively captures it causes are the

${ }^{1}$ Côte d'Ivoire before the 2010 electoral crisis made up of about $40 \%$ of the West African Economic and Monetary Union's GDP. It was one of the strongest economies in the sub-region. See Appiah, Anthony K. and Henry L. Gates (2010). Encyclopedia of Africa. London: Oxford University Press.

${ }^{2}$ See Ocheni, S. and Nwankwo, B. C. (2012). Analysis of Colonialism and Its Impact in Africa. Cross-Cultural Communication, 8(3), 46-54. doi: http://dx.doi.org/10.3968/j.ccc.1923670020120803.1189.

${ }^{3}$ Origin and culture has been a cause of conflict since the beginning of the world. Leaders incite people for a course by attacking their sense of belonging through origin as was done by Gbagbo and Ouattara during the 2010 election. 
radical also known as the Marxist structural theory and the liberal structural theory. The radical structural theory is presented by the Marxist dialectical school with exponents such as Karl Marx, Engel and V. L Lenin (Lenin, 1917; Bettinger, 1991). The Marxist argues from the stand that conflicts occur because of the exploitative and unjust nature of human society and domination of one class by another. They also blamed capitalism for being an exploitative system based on its relations of production and the division of the society into the haves and the have not (Oakland, 2005). The liberal structural theory argues that conflict is built into the particular way societies are structured and organised (Galtung, 1971; Faleti, 2006). The liberal structural theory looks at social problem, injustice, poverty, exploitation and inequality as the basic source of conflict in every society.

The exponents accused capitalist societies of being exploitative and that such exploitative is the cause of conflict in the society (Best, 2006). On the other hand, are the liberal structuralisms. Generally, the liberal structuralisms believe that, competing interest of groups tie conflicts directly into the social, economic and political organisation of the society as well as the nature and strength of social networks within and between community and groups (Folarin, 2015). Ross (1993) argued that in situations where economic and political disagreement and weak kinship ties are the defining characteristics of the society, the chances of negative conflict will result. According to the proponents, (liberalists) resources are the major cause of conflict between individual and groups within political systems and between nations. Oberschall (1978) argued that where existing structures are titled in favour of one group and others are disadvantaged, while seeing cultures as exclusive, create opportunity for the emergence of conflict and escalate if nothing is done to correct such situation.

From these two perspectives of the structural conflict theory that is, the Marxist and liberal perspectives, the liberalists offered a more convincing explanation on the causes of conflicts and the conditions under which they occur particularly as regards to the African conflicts. African conflicts are mostly due to competing interest of individual groups ${ }^{4}$ or nations states over scarce resources or struggle over power (Annan, 2014).

The post-election conflict of Côte d'Ivoire in 2010 was one of the many examples of civil wars in West Africa which was very violent ${ }^{5}$. The post-HouphouetBoigny power struggle was exacerbated by the controversies over nationality laws and eligibility conditions for national elections, particularly the presidential elections, which resulted in the disqualification of some prominent political ${ }^{4}$ African conflicts are mostly due to competing interest which are showcased during elections. There have been more conflicts via elections than any other cause in Africa. See Salehyan and Linebarger, (2013). Elections and Social Conflict in Africa. Climate Change and African Political Stability, Research Brief No. 6.

${ }^{5}$ Civil wars in West Africa especially in the contest of fighting for political power is common. The post-election conflict of Côte d'Ivoire in 2010 was one of the many examples of civil wars in sub-region such as in Liberia (1990-1998 and 2003), in Sierra Leone (1994-1999) in Guinea-Bissau (1998 and 2012), in Ivory Coast since 2002 and in Mali since early 2013. 
leaders, including Alassane Ouattara of the Rally of the Republicans (RDR) ${ }^{6}$. These issues made headlines during the presidential elections and resulted in violent clashes between the partisans of the two main contenders-General Guei and Laurent Gbagbo. Those clashes claimed the lives of over 50 people and a mass grave was subsequently discovered near the northern part of Abidjan suburb of Yopougon (United Nations to Côte d'Ivoire, 2003).

\section{Violent Conflict in Africa}

While some scholars assume violence as a social circumstance that corrupt the good human nature, psychologists hold the view that violence as an aggressive behaviour is not an instinct nor inherent in human nature but rather learned (Berkowitz, 1962; Faleti, 2006: p. 47). Therefore, the violent nature of conflict in West Africa could be explained to results from the frustration created by the unfair conditions in society (Dollard et al., 1939). This could be linked to "the want-get-ratio" where achieving one's goals in life is hindered by prevailing circumstances (Feierabends et al., 1969: pp. 256-257). Frustration, therefore, could be a tool used by political actors to instigate conflict. Dollard et al. (1939: p. 7) defined frustration as an interference with the occurrence of an instigated goal-response at its proper time in the behavioural sequence.

But does all aggression result from frustration? asked Berkowitz (1980: p. 19). He then supports the argument of Dollard et al. (1939) that anger instigates aggression and only occurs when "there are appropriate lives or releasers" (Berkowitz, 1980: p. 122, 136). The frustration and aggression theory, justifies why the youths ${ }^{7}$ are being forced to participate in electoral violence though it may be against their will. In a society where the gap between the rich and the poor is so wide, conflict and violence are inevitable. The high unemployment rate of youths, structural failure and irregularities in security pushes the youth into social vices especially political conflict that charade as a fight for national freedom. Political actors manipulate the youth due to their situation and use them to achieve their political ambition through violence.

According to Huntington (1968 cited in Sisk, 2008) political disorder is more likely to occur in societies marked by high levels of political participation but with slow or weak processes of political institutionalization such as Côte d'Ivoire. In essence, institutional functionalism draws a direct correlation between weak states and the phenomenon of violence. Thus, conflict is likely to erupt where the state fails to meet popular demands, leaving the masses in ${ }^{6}$ President Bédié instituted national identity laws after his victory over Alassane Ouattara in 1993 to side-line him and other competitive political actors from the race of presidency. The unclear definition of who an Ivorian was and what qualifies to run for presidency since 1993 has caused havoc in Côte d'Ivoire.

${ }^{7}$ The economic status of youth has been found to be a reason for their involvement in conflicts especially in African countries. See Yair, O and Miodownik, D (2016). Youth bulge and civil war: Why a country's share of young adults explains only non-ethnic wars. Conflict Management and Peace Science, 33(1): 25-44. https://doi.org/10.1177/0738894214544613. 
grinding poverty. According to Nathan (2000) where underdevelopment is coupled with inequality, violence may occur as expression of anger, frustration and fear. Such violence is more real if the state lacks institutions for addressing grievances, and even more apparent in periods of elections that offer the possibility of changing the status quo. The civil war in West African countries could be directly traced to the argument of Nathan (2000) as reported by researchers (Adebajo, 2002; Harris, 2004; Afisi, 2009: pp. 59-66; Matlosa et al., 2009; IPI, 2011, Salehyan and Linebarger, 2013; Annan, 2014; Bøås and Utas, 2014; Utas and Christensen, 2016). The weakness of institutions is most evident when states undergo the processes of economic, political and social change. The weak institutions $^{8}$ in African states is the main cause of violent electoral process. Development of political institutions lags behind social and economic change in many developing countries. As a result, the political playing field is skewed in favour of those in power and/or use the opportunity to manipulate elections for by all means victory. Moreover, political manipulation of ethnicity in the African countries is now seen as the transfer of state resource to the group who has a member in power. Therefore, political actors trade state resources in return for the votes of citizens.

Since the end of cold war, conflict shifted from the paradigm of inter-state to intra-state, that is, internal conflicts within a state (Annan, 2014). This however contradicted the idea that the world will once again be peaceful. These new form of internal conflicts have been the tenet sources of human suffering through gross violation of human rights ${ }^{9}$ and destruction of properties. The inadequate knowledge of the root cause and drivers of the current phase of conflict in countries incapacitate potential solutions.

\section{Côte d'Ivoire and Conflicts}

Côte d'Ivoire gained independence on 7 August 1960. The name of the country was officially changed to Côte d'Ivoire from "Ivory Coast" in October 1985. Felix Houphouet-Boigny was the first president of the nation (from 1960 to 1993). During his era the country was stable and progressively developed in a similar pattern like neighbouring countries such as Ghana. After the era of HouphouetBoigny, there has been a coup-d'état in 1999, a civil war in 2002 and a post-election crisis in 2010. Before the death of Houphouet-Boigny in 1993, he made Alassane Dramane Ouattara first Prime Minister of Côte d'Ivoire in 1990 which brought about a succession conflict between Ouattara and Henri Konan Bédié ${ }^{8}$ The weakness of institutions is most evident when states undergo the processes of economic, political and social change. Independent Electoral bodies are not solely independent in the African contest. They are appointed by the government in power which create a sense of "indebtedness" when it time to oversee elections. The Independent Electoral Commission of Côte d'Ivoire stood it grounds in the election because of the backing of the ECOWAS, AU and the UN through election treaties and protocols on democracy and good governance.

${ }^{9}$ Human right watch report on the killings in Abidjan after the presidential run-off elections on 26 January 2011. See Human Rights Watch (2011). Côte d'ivoire: Violence Campaign by security Forces, Militias. Available at

http://www.hrw.org/news/2011/01/26/c-te-d-ivoire-violence-campaign-security-forces-militias. 
(President of the National Assembly at the time). Although the struggle for a successor for the late President Houphouet-Boigny was not tagged as a conflict it had a negative impact on the country. Ouattara lost the succession of the presidency to Bédié to start a new regime from 1993.

The 24 December 1999 coup-d'état which ended the reign of President Bédié was to source for better working condition of young soldiers ${ }^{10}$. The military took over the once peaceful country and changed the rule from democratic (Badmus, 2009). It was obvious that the civil war in 2002 was partly as a result of the failed coup-d'état on 19 September, 2002 (Konate, 2004). The resulting rebels in the north that stood against the government of President Laurent Gbagbo. The 2010 post-election crisis resulted from the refusal of Laurent Gbagbo to accept that Alassane Dramane Ouattara won the 2010 presidential run-off elections despite the high voting turnout which showed that Ivoirians' were ready to end crisis in the country (Banegas, 2011).

The article is based on full day interview sessions with each of the selected fifteen key informants (UN and ECOWAS election observers, ECOWAS country representatives, past government official of Côte d'Ivoire, Researchers and Lecturers in the Political Science field, Leaders of Civil Societies and NGOs that were active during the 2010 post-election crisis, military personnel) between the month of April and August in 2017; three briefings on the crisis; official documents, such as the Linas-Marcoussis agreements, United Nations (UN) reports, European Union (EU) reports and Carter Center election observation reports; press material and journal publications.

This study employed the Marxist and liberal structural theories of conflict to investigate the causes and drivers of the 2010 post-election conflict in Côte d'Ivoire. The research questions addressed were:

1) What were the main causes and/or drivers of the post-electoral conflict in Côte d'Ivoire in 2010?

2) To what extent did the 2010 post-electoral conflict impact the people of Côte d'Ivoire and the West Africa sub-region?

\section{Presentation of Results}

\subsection{Causes of the 2010 Post-Election Crisis in Côte d'Ivoire}

Different views on the causes of the post-election crisis were gathered. The most prominent can be grouped under; political, national identity, land ownership and religion.

\section{Political}

The post-election conflict in 2010 was just a materialization of the division that diverse interpretation of legal instruments governing the political system of the country had created since the 2002 conflict with regards to the various dec-

${ }^{10}$ The United Nations Mission in Côte d'Ivoire was due to the 24 December 1999 coup-d'état which ended the reign of President Bédié. Further read at https://peacekeeping.un.org/en/mission/past/minuci/background.html. 
lination of the country's policy on immigration despite the Linas-Marcoussis ${ }^{11}$ and Ouagadougou ${ }^{12}$ Agreements in 2003 and 2007 respectively. This misinterpretation of the legal instrument could be traced to the policy of Félix Houphouet-Boigny, which was based on national solidarity and unity in relation to foreigners, to build the economic and political strength of the country ${ }^{13}$. However, the place of this policy began to decline after the regime of Félix Houphouet-Boigny. The three key areas of misunderstanding or that faced litigation in interpretation were who was an Ivorian (national identity)? what makes one a landowner? and other thematic laws of governance such as who qualifies to run for presidency in the country? Misunderstanding of the 2007 peace agreement and misleading interpretation of agreement to favour each group's stand for example in the 2002 conflict continued till 2010. For instance, while one group interpreted the Linas-Marcoussis Agreements, the Accra Agreements and that of the UN to mean that the votes should be recounted, the other group interpreted it to mean that there should be a succession of power ${ }^{13}$. Clarity of peace agreement not defined for political actors rather increased the division in the nation instead of resolving the conflict of 2002, which continued to 2010. Therefore, the conflict was purely based on electoral diverging views on the political principles of democracy.

In the 1995 election, many writers reported Gbagbo and the Ivorian Popular Front/Front populaire ivoirien (FPI) to have launched "active boycott" when the Baoulés-(the largest subethnic group in Côte d'Ivoire)—were killed in Gagnoa (the eighth largest city in the country made of bété ethnic group and is the capital of the Gôh region in central western Côte d'Ivoire). This was also instrumental in setting one ethnic group against the other in the succeeding election years and played a significant role in the 2010 post-election conflict in Côte d'Ivoire ${ }^{13}$. The people of Côte d'Ivoire had no problem of appropriation or expropriation on migratory movement until 2010. The conflict sent about 5 million Burkinabe's back to Burkina Faso. Despite the division and dysfunctional social cohesion, unity still existed at the background. A key informant ${ }^{13}$ who was part of the Peace Building Fund explained as follows:

${ }^{11}$ The Linas-Marcoussis Agreement created a Government of National Reconciliation to be in charge of preparing a timetable for holding a credible and transparent national elections, rebuilding the security forces and organizing the disarmament of all armed groups. The agreement was via a Round Table of the Ivorian political forces from 15 to 23 January 2003 in Linas-Marcoussis.

${ }^{12}$ The Ouagadougou Agreement was signed in the Burkinabe capital on 4 March and President Compaoré was named Facilitator in his capacity as Chairman of the Heads of State and Government of the Economic Community of West African States (ECOWAS). On 26 March, President Laurent Gbagbo and Guillaume Soro, leader of the Forces nouvelles, signed a supplementary agreement designating the latter as the new Prime Minister and according him specific powers for the purpose of implementing the Ouagadougou Agreement.

${ }^{13}$ Interview with experts such as Program leaders at the Friedrich Naumann Foundation for Freedom (a German political foundation that promotes civil, political and economic freedoms); African Union and ECOWAS electoral observers; Advisors for military and security affairs of ECOWAS; political scientists and researchers from "Centre de Recherche Politique d'Abidjan; University Lecturers; representatives of ECOWAS in Côte d'Ivoire; University students who were on campus during the crisis; and presidents and founders of NGO that contributed to the resolution of the crisis. 
"...when someone resides in Côte d'Ivoire and he is sensitive enough, he can see that there is no conflict amongst the people on ground. The continuous togetherness of the people in the country makes it difficult to say that the conflict was based on ethnic, religion or geopolitical origin of citizens although there are crises in movement. Political actors launched attack on certain ethnic groups to use it as an instrument to fuel ethnic conflict. Burkinabe's are living peacefully from Soubré to Gagnoa in the country. Liberian militia were used to kill Burkinabe which caused the Republican Forces of Côte d'Ivoire (FRCI) mostly Burkinabe's to revenge on other citizens. The populace has never gone into conflict on any issue like land pressure or ethnicity except the manipulation of politicians who exploited these identities as grounds to manipulate the people of Côte d'Ivoire for the political ambition".

Therefore, the nature of conflict in Côte d'Ivoire was political. Politicians used the armed forces available to them or identity of the people to instrumentalize conflict. The post-election conflict was portrayed as a civil war ${ }^{14}$ in media according to electoral observers but the nature was actually a political war. It was a battle for power between the army of the nation under outgoing President Gbagbo and Ouattara with their militia and young supporters willing to fight for their leaders. One can freely travel to all part of the nation and observe peace amongst the citizens.

Every rebellion comes with both positive and negative impacts. Unfortunately, the negative impacts are experienced by civilians which are mostly used as bait to call for referendum or changes in political ruling or laws. The 2002 civil war had a positive impact on the condition of service of junior military staff in the country. Moreover, the rebellion from 2002 and the 2010 post-election conflict placed demands on political inclusion specifically on the fringe of the political class as a positive impact. The agreements signed during these two conflicts by the involvement of regional organization and international communities have helped to regulate the incomprehension on the legal and political laws on inclusion in the political race ${ }^{11}$. Several political actors, who could not have qualified to participate in elections due to the fringe in the law had the opportunity after the agreements which were in part brought about by rebellion ${ }^{13}$. The Advisor for military and security affairs of ECOWAS ${ }^{13}$ posited that:

"...usually, those who make rebellion seek to justify even their insignificant actions."

The country is not yet immune from electoral conflict because the Rally of the Republicans/Rassemblement des républicains (RDR) has not yet solved the problem of social cohesion and national reconciliation. Furthermore, the RDR is

${ }^{14}$ The three briefings published in African Affairs in 2011 used for this study were; Winning Coalition, Sore Loser: Côte d'Ivoire's 2010 Presidential Elections by Thomas J. Bassett, "It's Sheer Horror Here": Patterns of violence during the first four months of Côte d'Ivoire's post electoral crisis by Scott Straus and Post-election crisis in Côte d'Ivoire: The Gbonhi war by Richard Banegas. 
afraid that the Democratic Party of Côte d'Ivoire/ Parti démocratique de Côte d'Ivoire (PDCI) or the Ivorian Popular Front/Front Populaire Ivoirien (FPI) will come to power in 2020 according to AU and ECOWAS electoral observer ${ }^{13}$. He affirms that there are still frequent words of hatred and division circulating in the political arena. Living together as a republic or a nation is yet to be understood by most of the citizens. Although, there is no religious civil war or ethnic war in the country, the media showcased the post-electoral war to be a religious civil war in order to attract international interventions in terms of funds and legal instruments that brought about positive agreements in the country. Thomas J. Bassett in his briefing reported that Côte d'Ivoire was at the verge of civil war at the beginning of April 2011 ${ }^{14}$. Civilians were victims of the political battle between Gbagbo and Ouattara. The contradicting victor declaration of Ouattara and Gbagbo after the run-off by the Independent Electoral Commission (IEC) of Côte d'Ivoire and Constitutional Council respectively caused the lives of 462 citizens, displaced 750,000 and made 128,000 refugees ${ }^{13}$. Attacks and violence against civilians continuously increased until the UNOCI was authorized by the UN Security Council to use all possible and necessary means to protect civilians from physical violence from the forces of the two leaders. According to the documentation of UN on the crisis, about 1000 civilians were dead, one million people internally displaced and 100,000 civilians forced out to neighbouring nations as at the time of the arrest of Gbagbo ${ }^{14}$.

A post-conflict survey for the 2010 post-electoral crisis across the country revealed that majority of the populace were victims of political manipulations. The conflict was also referred to as a politico-military as the two realities were expressed $^{13}$. The stand of the outgoing president (Laurent Gbagbo) on the outcome of the 2010 elections led to the electoral dispute that resulted in the disastrous tragedy in Côte d'Ivoire. The reactions between loyalist to the two parties (pro-Gbagbo and pro-Ouattara) and both international and regional sympathizers escalated the whole situation. The desire to win by both political actors especially the incumbent, made them desperate and things went overboard especially after one of the presidential candidate declared his support to Alassane Ouat$\operatorname{tara}^{13}$. Arms and ammunitions were on the increase because the two conflicting parties had military support from others loyal to their cause thereby escalating the crisis and endangering the peace and the security of Côte d'Ivoire and her people. The refusal to accept the elections results led to political tensions and destruction of lives and properties especially the human rights of women and children were violated during the conflict ${ }^{13}$.

The incumbent violated rules that impeached democracy such as interference in election administration, self-declaration as winner via constitutional council and the breach of constitutional rules on election procedures and protocol on good governance and democracy ${ }^{13}$. Moreover, a curfew was declared a night to the run-off by the incumbent which hindered the process of free and fair election. 


\section{National identity}

Although the conflict was purely political, it manifestation centered on the concept of citizenship and identity ${ }^{13}$. The unclear definition of a citizen and eligibility criteria for political office in the country was a backdrop for Côte d'Ivoire, and became a machinery to the 2010 post-election conflict. The stand of having both parent being Ivorians to prove citizenship was debateable. Although this issue was duly clarified by the Linas-Marcoussis and Ouagadougou agreements. Moreover, the outgoing president (Laurent Gbagbo) considered the position of the international community as biased in favour of the opponent and the result was an imposition by the international community ${ }^{13}$. The followers of the outgoing president (pro-Gbagbo) showcased the opponent as the candidate of the international community while their candidate was for the true Ivoirians. This ideology and message made others who claimed the status of true Ivoirians skeptical in acknowledging the opponent as the President elect of Côte d'Ivoire in 2010.

The term "Ivorite" initiated by President Bedié was interpreted different by key informants in this study. While one understood the term as a cultural concept for the national identity to show proudness of being Ivorian others saw it as a political instrument invented to drive away opponent ${ }^{13}$. The term was supposedly meant to unify the country in line with other ideological and cultural paradigm such as Pan-Africanism. Unfortunately, succeeding politicians misinterpreted the term and manipulated the populace for their self-interest. Both the political parties and geopolitical regions either suffered or were favoured based on the term. The term despite its intentions which is only known to the initiator frustrated political leaders mostly from the north.

In 2002, one of the actors of the conflict based their reasons on the exclusion from the political class from the barriers set from the supposed term or meaning of a true Ivorian. According to the representation of ECOWAS in Côte d'Ivoire ${ }^{13}$ :

"...the concept of "Ivoirite" was not xenophobic. It was a concept to show one's pride of being an Ivorian. But at the accession of Gbagbo, the concept was taken as a political strategy to oppose the "foreigners" (immigrants)."

A key point of the EU election observation repor ${ }^{15}$ was the xenophobic and nationalist discourse from the camp of Gbagbo during the campaign for the run-off in 2010. Violence was noticed as Gbagbo's supporters pushed the agenda of true Ivorian or Ivoirite to gather most of the southern citizens to their course. The economic agenda of President Felix Houphouët Boigny which allowed migrants from Burkina Faso and other parts of the sub-regions to settle in the northern region of Côte d'Ivoire was reported as the root cause of who is a true Ivorian? ${ }^{13}$ The lack of clear and detailed laws on immigration status in relation to

${ }^{15}$ The Final Report of the EU observation mission (EUEOM/2010/08) on 25 January 2011 was consulted. It is a comprehensive analysis of the context of the presidential election, the relevant data and submits recommendations in view of future elections in Ivory Coast. 
political governance on the part of the first president has a major part to play in the instrumentalization of identity to fuel conflicts in the nation. The identity issues further affected the nationality status of one who is qualified to run for presidency in Côte d'Ivoire. The round table agreement in 2003 made it clear that if one of the parent of the citizen is an Ivorian then the person qualifies to run for presidency ${ }^{11}$. The interpretation of the agreement differed from political camps to the citizen due to their separate individual interest and agenda in the election $^{13}$. Alassane Ouattara felt targeted by some of the legal instruments including the constitution at the time on his eligibility to run for the highest office in the country. These misunderstandings made the political class feel reproached and were used by incumbent president in the 2010 post-election conflict ${ }^{15}$.

\section{Land Ownership}

The political causes could not have escalated the conflict if pending issues like "what makes one a land owner" and "who is a true Ivoirian" was clear in the constitution. The Burkinabes and Ivoirians were united as one country before independence. Land ownership became an issue when President Felix Boigny said that the development of Côte d'Ivoire is based on agriculture. The Ivoirians started requesting for their land from the Burkinabe's stating that they (Ivoirians) need the land for farming and other activities. Marginalization of immigrants who have lost their origin (of citizenship) after settling in Côte d'Ivoire generated anger and frustration. That divided the country to rally support behind the candidate that have a vision for them ${ }^{13}$. This shows again that the different ruling policies and agenda of the first president and his successors is fundamental to the 2010 post-election conflict. The inability of successors to accept both indigenes and immigrants as part of the country divided Côte d'Ivoire into two parts ${ }^{13}$.

The policy of President Houphouët Boigny on land acquisition empowered the one who worked on the land as it stated that "the land belongs to the one who enhances it". The policy is not clear and can be misinterpreted. Political actors used the same policy to manipulate some ethnic groups against others as narrated by a key informant ${ }^{13}$ :

“The Gbich Journal tries to link the ethnic groups in Côte d'Ivoire to a particular craft or profession. For instance, the bété are not known for farming, but are recognized for music and football. During the conflict, the same bété people who don't "enhance land" were claiming ownership of the lands they have given to the Burkinabes to work on for years. Political manipulation misinterpreted the policy on land ownership to generate conflict between the Burkinabes and the bété. After the political exploitation in 2010, things are being restored to what it used to be but depth of the impact cannot make peace or social cohesion be as it was before the 2010 post-election conflict."

Land ownership was part of the key areas addressed in the Linas-Marcoussis agreement ${ }^{11}$ under the Law 98-750 of 23 December 1998 on Rural Land Tenure. 
The agreement proposed the design of an appropriate landowner holding right.

\section{Religion}

Religion and migration issues compounded the problem of national identity. Some of the presidential candidates used the faith of the citizens and type of immigration status to draw support for their political ambition. For instances, Mr. Ouattara during one of his campaign claimed that:

".... that the people in power do not want to let Muslims contest for politi-

cal position and to come into government in Côte d'Ivoire ${ }^{13}$."

The opposition took over the northern part of the country when they failed to conquer Abidjan and separated the jurisdiction of ruling between the north and south. This was made possible due to the unresolved misunderstanding on who was an "Ivoirite" and driven by religion and migration status of citizens. Statements from presidential candidates such as:

“...I am a Muslim from the north."

Further confirmed that the political leaders based their campaign on their affiliation to a religious group and origin in the country. According to the report of the US Central Intelligence Agency (CIA), Côte d'Ivoire as a nation had no ideological problem and the 2010 post-election conflict was not based on faith or origin (Cook, 2011; Konate, 2014). Rather, politicians instrumentalized the populace based on who they are to gather support for their ambition. It was evident that the conflict was fuelled on the grounds of ethnicity, religion and geopolitical status of citizens, however, the country had and has no ethnic or religious conflict ${ }^{13}$. There was no war or conflict between Catholics and Muslims; Protestants and Muslims; Geopolitical North and South; nor ethnic groups in Côte d'Ivoire. Political actors used these identities to create dysfunction in social cohesion for their political ambition. However, briefing by Scott Straus ${ }^{14}$ reported sentiments of fear and religious civil war by a sentence such as:

"'We're afraid', said the brother of a man whose throat was slit by pro-Gbagbo forces, and '[Muslims are] not safe' in Abidjan, said an Imam."

The fear instilled by either pro-Gbagbo or pro-Ouattara forces sent the signal of religious and ethnic or geopolitical war.

It was evident that identity ran through the four major causes of the 2010 post-election conflict in Côte d'Ivoire. Identity which was theoretically resolved in the 2007 Ouagadougou agreement played out in the conflict ${ }^{13}$. Unfortunately, the political actors of the 2010 round off were from the north and south geopolitical zones which divided the nation according to geopolitical affiliation. On the basis of religion, both were from different faith of believe and also had different condition of citizenship. The 2010 post-election conflict was engineered by politics but it rode on the wheels of identity.

\subsection{The Impact of the 2010 Post-Election Conflict in Côte d'Ivoire}

Internal impact of the post-election conflict 
The impact of the 2010 post-election crisis in Côte d'Ivoire up till date was adverse on the citizens as well as neighbouring countries in the West African sub-region. During an interview with a Lecturer ${ }^{13}$, the following information was obtained:

“...officially, 3000 people were reported as killed, many became refugees in their own country and others traumatised. Many lives and properties were lost; all schools were closed down including the popular university called Abobo Adjamé University which was badly destroyed. Many public infrastructures were almost completely destroyed during the crisis. Reconstruction and renovation of some of the infrastructures, especially the Abobo Adjamé University which was renamed Université Nangui Abroguoa including other universities are of recent."

The report of the dead was progressive from $462^{16}$ to $1000^{14}$ when Gbagbo was arrested and to $3000^{13}$ after the investigation on the crisis was over. Abidjan city which was once a haven became a dangerous and death zone during the 2010 post-elections conflict in Côte d'Ivoire. According to a University of Cocody student ${ }^{13}$, when one is caught in Abidjan in those times, the first question was his identity, that is, either a southerner or northerner. What followed was injury or death depending on the group of the rebels (pro-Gbagbo or pro-Ouattara) that caught the individual and his origin (north or south of Côte d'Ivoire).

It was observed that almost every family in the country lost someone; a beloved friend, son, brother, sister etc. Some were killed and others imprisoned. The death or imprisonment of family heads (the men) was a big blow on both nuclear and entire extended families and even could go as far as a whole community ${ }^{13}$. Fathers are the bread winners in most African families. The disappearance of this key figure distorts family development which further affects the communities and nation as a whole. Therefore, the 2010 post-election conflict resulted in social tragedy in Côte d'Ivoire. The entire development sector of the country was affected by the conflict; many of the political actors die regularly even after the crisis and others are in exile; the economy, education, and health system were deregulated; and very affected system or sector needed a total renovation and/or reformation.

The impact of the 2010 post-election conflict is still visible today in both the political arena and the society. The division in the political class is so obvious today and the society can feel the impact. The 2010 crisis created a split in social cohesion, manifesting currently in the form of distrust amongst citizens ${ }^{13}$. Although the conflict is over, the chaos it created in social cohesion is daily witnessed within political parties. There is a certain kind of heaviness in the Ivorian society born out of mistrust. Unfortunately, a certain category of the population was tag as "not to be trusted" due to the conflict. The unforgettable pains still reflect in political debates and arguments.

${ }^{16}$ The Carter Center International Election Observation Mission to Côte d'Ivoire report page 64-77 on Election-Related Voilence. 
According to an AU and ECOWAS electoral observer ${ }^{13}$, the poor turnout in the 2015 elections was one of the present impact of the 2010 post-election conflict. The turnout of the 2010 elections was reported to be about $80 \%{ }^{14}$, the highest in the country since democracy started. The country was still divided as at 2015. These were some of the observations during the 2015 elections:

“...The division of the populace created by the 2010 post-election conflict still lingered on during the 2015 election which had less than half of registered voters $(41 \%)$ participation. The citizens have dissociated themselves from politics and political decision making like voting. There was the notion that their participation in the electoral process was just a formality and had no significant role in who becomes the president at the end of the day. The society saw the 2015 election as a charade and had nothing to do with the outcome as well as the security of citizens. There was no confidence in the Independent Electoral Commission. Similar situation led to the post-election conflict in $2010^{13}$."

The effect of the division extended to the universities and even into families. Students of the University of Cocody, now known as Université Felix Houphouet Boigny, became a target of Ouattara forces because majority of the members of the association called "Federation Estudiantine et Scolaire de Côte d'Ivoire (FESCI)" that is Ivorian Student Association supported Gbagbo. According to the student of the said university, movement of student was restricted due to the death threat from Ouattara forces. Furthermore, she narrated that:

"...families were divided based on the candidate each member supported. Laurent Gbagbo was said to be the candidate of the people of Côte d'Ivoire while Ouattara was the candidate of the international community. The Ivoirians wanted a president from Côte d'Ivoire, not from the international community whereas the international community which were dominant in the north as well as the forces of Ouattara harassed electoral observers for Gbagbo in the northern part of the country ${ }^{13}$."

The university halls of residence were targeted by pro-Ouattara forces when they launched an attack in Abidjan on 31 March 2011 because most of the halls of residence have been transformed into barracks through the Fédération Estudiantine et Scolaire de Côte d'Ivoire (FESCI) under the militia of Gbagbo ${ }^{14}$. The university campus became scary because students through the thousands of guns distributed to them were empowered to play an active role in the battle between Gbagbo and Ouattara.

The conflict created insecurity in Côte d'Ivoire, caused division amongst the citizens, generated internal refuges and violated human rights ${ }^{13}$. The figures of the internal displaced citizens varied from amongst the reports, that notwithstanding, all reported over 100,000 citizens losing their homes due to the postelection conflict in 2010.

External impact of the post-election conflict 
The impact of the Ivorian conflict on the sub-region was enormous and can be measured at several levels, precisely at the political and diplomatic level, socio-economic level and at the humanitarian level ${ }^{13}$. The conflict generated many refugees in the nearest countries of Côte d'Ivoire e.g. Ghana, Burkina Faso, Liberia, Mali which created economic and social challenges for the countries hosting the Ivorian refugees ${ }^{13}$. Foreign investment shifted to neighbouring countries thereby improving their economy. The conflict further created insecurity issues and tensions in neighbouring countries by the spread of "illegal" or "uncontrolled" weapons that were used during the conflict ${ }^{13}$. Many of the citizens working in Côte d'Ivoire were killed during the conflict. Newspapers reported that over 5 million Burkinabe returned to their home country although few of them came back to Côte d'Ivoire after the conflict was over because their establishment was in the country. Sub-regional trade with Côte d'Ivoire since the 2010 post-election conflict has reduced because of perceived and pending insecurity in the counry ${ }^{13}$.

Côte d'Ivoire has a unique role as an economic engine in West Africa, a port of access to international trade to several landlocked countries, and a history of deep integration with other countries through trade, migration and finance flows. The effect of Côte d'Ivoire's instability in West Africa extends beyond its immediate neighbours. Benin has many workers in Côte d'Ivoire despite the fact that it is separated from the country by Ghana and Togo to the West and Burkina Faso to the North-West. It was estimated that the impact of conflict on development extended to about $800 \mathrm{~km}$ radius. The instability in Côte d'Ivoire increased the perception of political and economic risks in the whole region, scaring off foreigner investors not only from Côte d'Ivoire but also from the sub-region. In February 2011, Côte d'Ivoire defaulted on a \$29 million Eurobond interest payment. The bonds had been placed only in April of 2010. Yield on Ghana's Eurobonds jumped from less than $6.3 \%$ to more than $6.8 \%$ in four days following the defaults in Côte d'Ivoire ${ }^{17}$.

The conflict also proliferated small arms into the sub-region that threatened the security of neighbouring countries ${ }^{13}$. The other regions surrounding Côte d'Ivoire such as Ghana, Liberia, Burkina Faso, Guinea, Togo, Benin, Sierra Leone and Mali were also affected by this crisis in terms of refugees and returnee's inflow, trade relations, investments, banking and financial institutions, employment and free movement of persons. Intervention from international organizations like UN Peacekeepers were also negatively impacted by the magnitude of the conflict.

\section{Discussion of Findings}

The 2010 post-election conflict in Côte d'Ivoire manifested the three dimensional definition of conflict by Bernard Mayer (2000). The perception dimension

${ }^{17}$ Political instability affect the status of the Eurobond as described in Hunting for Eurobonds: Views split on sub-Saharan Africa's debut in the international markets. Available at https://www.un.org/africarenewal/magazine/april-2014/hunting-eurobonds. 
of the conflict was mostly in media where it was painted as a civil war agitated by ethnicity and religion (Straus, 2011; Konate, 2014). The feeling dimension which encompass emotional response to the conflict such as bitterness, anger and fear still lingers on in the country, especially now as the nation prepares for another election in 2020. The violent and destructive action of the conflict was obvious. About 3000 people were reported dead officially. Infrastructure including university facilities was vandalized during the conflict ${ }^{13}$. A conflict could start from any of the three dimension and escalate to others or be stopped during it maturing period. The later was not the case of Côte d'Ivoire in 2010. It started as perception amongst the political actors on who won or lost. Both parties were convicted that they won the election and through verbal exchanges incited fear and anger by touching on sensitive issues in the country then went forward to use armed forces available to take charge of the streets in Abidjan (Banegas, 2011; Bassett, 2011; Piccolino, 2011; Straus, 2011). The conflict added to the list of many violent election conflict in West Africa (Annan, 2014).

The post-election conflict in 2010 was purely political. The misunderstanding and unwillingness to accept ballot rule and the Pretoria agreement in 2005 by the political parties with the UN after the declaration of the run-off results by the Independent Electoral Commission of Côte d'Ivoire was the root cause of the violence (Piccolino, 2011; Garavoglia, 2013). Political civil wars are common in the West Africa. Other countries which had similar situations are Liberia, Guinea-Bissau and Sierra Leone (Aning and Bah, 2009). In Africa, election has been the major cause of 685 conflicts between the 1990 and 2011 (Salehyan and Linebarger, 2013). This is not accidental since elections create a competing grounds for rivals to seek power. The lack of clearly defined constitutions and the weak independent electoral bodies such as was evident in Côte d'Ivoire in 2010 elections where incumbent could refuse election results and declare himself a winner by constitutional council was an unavoidable bait for conflict ${ }^{13}$. The term post-electoral or post-election suggest that the conflict resulted from elections and therefore, confirms the root cause to be political. However, political actors themselves, in most situation, do not get involved or physical affected by the conflict. They rather use pending misunderstanding and sensitive issues that create differences in the society to drive the conflict for their political ambition. The two main of such causes to be discussed are national identity and land ownership policy. This argument has been in the system since the era of President Bedie when he invented the Ivoirite terminology in a battle with Ouattara (Konate, 2004, 2014). The issue that needed attention then which was root to the 2010 post-election conflict were: the identification of the population, a new law on the ownership of the land and a new electoral law.

Côte d'Ivoire was built on the ideology of "everyone belongs here" whether indigene or settlers from neighbouring countries. President Felix Houphouet Boigny saw the economic benefit of making migration to the country liberal ${ }^{13}$. Unfortunately, the regime of the first president did not document in policy the conditions of becoming a true Ivorian when you are an immigrant. Since immi- 
grant had the right to vote, it could have been interpreted that they have the right to political leadership until the battle between Laurent Gbagbo and Alassane Ouattara started in 2005. The Ouagadougou agreement in 2007, which constitute the most recent in a series of partially implemented peace accords, aimed at reunifying Côte d'Ivoire which was largely divided between a governmentcontrolled southern region and a rebel-controlled zone in the north since the outbreak of a civil war in 2002, partly resolved the issue of identity at the political level ${ }^{13}$, without educating and sensitizing the populace of the clarification in policy about identity. The term "Ivorite" by President Bedié which was became a weapon of mass destruction during the 2010 elections. The instigation that a true Ivoirite is one having both parents as indigenes naturally forced all residents with foreign origin (international community) to rally behind the candidate with like identity and vice versa for the "true Ivoirite". The mere use of the adjective "true" create tension and builds anger and bitterness, that is, conflicts as feeling (Mayer, 2000). The 2010 post-election conflict would have taken a different dimension if both political actors were from the same background of nationality. The use of identity as a driver by the political actors manipulated most of the citizens to participate in the conflicts with the understanding that they were fighting for a worthy course to preserve their true identity. Little did they know that it was a ploy for political power as a team member of the Peace Building Fund informed ${ }^{13}$. The attention of the citizens was shifted from the ballots outcome to who they are or origin. The geopolitical division of the country was as a result of the settlement of the two identities, that is, the settlers mostly from Burkina Faso in the north and indigenes mostly in the south of Côte d'Ivoire.

Identity further played a key role in land ownership. The immigrants are mostly farmers. The land ownership policy of President Felix Houphouet Boigny in essence made the farmers who enhance the land the owners and not the indigenes that dwelt or settled on it first ${ }^{13}$. Attacking the identity problem directly collapsed this policy and empowered indigenes to begin claiming lands they had giving away to be enhanced by immigrants for almost 20 years. Weak institutions on the basis of unclear policy and ambiguous statement empowered political actors to interpret constitutional laws to suite their course of action. Therefore, the conflict on land was as a result of the manipulation of the land ownership policy of the first president by loyalties of the incumbent in 2010 on the ideology of true Ivorian.

The "identity of who a true Ivorian was" which was not clearly defined by the constitution of Côte d'Ivoire in 2010 was the instrument used by political actors to involve the populace in their political conflict thereby breaking social cohesion, family ties and destroying economic relationship of the country with the international communities and traders from the sub-region.

\section{Conclusion}

Conflict is inevitable in all human relations, but it is not always desirable, nor is it always profitable. When not managed properly, the cost in human lives, prop- 
erties, political, socioeconomic opportunities could be disproportional with the desired outcomes. Several factor have been attributed to the cause of the 2010 post-election conflict but main cause and driver identified as the "engine" to the electoral violence were; political flaws or ambition and national identity respectively. This political standoff resulted into clash between political parties thereby endangering human lives and properties. The crisis affected the soil, economic and political environment of the country. The effect of this crisis led to an increase of refugee flow into neighbouring countries such as; Ghana, Benin, Togo, Burkina Faso, Liberia and Sierra Leone, thereby increase the instability and tension within the sub-region.

The political state of Côte d'Ivoire is very sensitive and necessitates pragmatic actions considering the fact that the country will be ascending for another election in 2020 despite the failure of the policy of reconciliation. It is now common phenomenon that conflicts most especially in Africa arise from disparity amongst ethnic groups in terms of ethnic or religious background which therefore metamorphose, into political conflict. On the contrary, the 2010 post-election conflict descending from political to national identity and affected ethnicity and religion.

\section{Recommendations}

Efforts should be made through policy reforms, awareness creation and education to re-conceptualise the concept of citizenship and aboriginal. These two factors were central to the 2010 post-election conflict and could be traced to other civil wars in the sub-region. The post-conflict peace initiative needs to be developed in order to return the country back to normalcy. Awareness on the need for democratic governments is continually increasing among citizens and will continually make citizens to use any means available to clamour for the entrenchment of democratic governance should their peaceful efforts be met with forceful and undemocratic responses from government. Strong institutions (judicial and security systems) should be built to create a medium to address the grievances of citizens on time before any politician capitalizes on their vulnerability to instigate civil war. This study was limited by scope of knowledge (only experts were considered) of the respondents interviewed and the number of times interviews were organized and the period of data collection. Further research should consider visiting locations that the conflict was dominant to interview affected families and people to validate the results from the experts which was the focus of this study.

\section{Acknowledgements}

This work was extracted from the master's thesis of Denis Adesina Daniel, submitted to the University of Ibadan under the ECOWAS Nnamdi Azikiwe Academic Mobility Scheme (ENAAMS). The research was sponsored by the Association of African Universities (AAU) internship grant at the Abidjan Political Research Center. The current employment of the first author bears no responsi- 
bility for the information in this article. All key informants are appreciated for their participation. We also acknowledge the rigorous work of the anonymous reviewers and the Editor.

\section{Conflicts of Interest}

No potential conflict of interest.

\section{References}

Adebajo, A. (2002). Building Peace in West Africa: Liberia, Sierra Leone, and Guinea-Bissau. Boulder, CO: Lynne Rienner Publishers.

Afisi, O. T. (2009). Tracing Contemporary Africa's Conflict Situation to Colonialism: A Breakdown of Communication among Natives. Academic Journals, Philosophy Papers and Reviews, 1, 59-66.

Aning, K., \& Bah, S. A. (2009). ECOWAS and Conflict Prevention in West Africa: Confronting the Triple Threats. New York: New York University, Centre on International Cooperation.

Annan, N. (2014). Violent Conflicts and Civil Strife in West Africa: Causes, Challenges and Prospects. Stability: International Journal of Security \& Development, 3, 1-16. https://doi.org/10.5334/sta.da

Badmus, I. A. (2009). Even the Stones Are Burning: Explaining the Ethnic Dimensions of the Civil War in Côte d'Ivoire. Journal of Social Science, 18, 45-57. https://doi.org/10.1080/09718923.2009.11892665

Banegas, R. (2011). Post-Election Crisis in Côte d'Ivoire: The Gbonhi War. African Affairs, 110, 457-468. https://doi.org/10.1093/afraf/adr025

Bassett, T. J. (2011). Winning Coalition, Sore Loser: Côte d'Ivoire's 2010 Presidential Elections. African Affairs, 110, 469-479. https://doi.org/10.1093/afraf/adr027

Berkowitz, L. (1962). Aggression: A Social Psychological Analysis. New York: McGraw Hill.

Berkowitz, L. (1980). The Frustration-Aggression Hypothesis. The War System: An Interdisciplinary Approach.

Best, S. G. (2006). The Methods of Conflict Resolution and Transformation. Introduction to Peace and Conflict Studies in West Africa: A Reader. Ibadan: Spectrum Books Ltd.

Bettinger, R. L. (1991). Marxist and Structural Marxist Perspective of Hunter-Gatherer. In: Hunter-Gatherers, Interdisciplinary Contributions to Archaeology (pp. 131-149). Boston, MA: Spring. https://doi.org/10.1007/978-1-4899-0658-8

Bøås, M., \& Utas, M. (2014). The Political Landscape of Postwar Liberia: Reflections on National Reconciliation and Elections. Africa Today, 60, 47.

https://doi.org/10.2979/africatoday.60.4.47

Cook, N. (2011). Côte d'Ivoire's Post-Election Crisis (p. 54). Congress Research Service.

Dollard, J., Miller, N. E., Doob, L. W., Mowrer, O. H., \& Sears, R. R. (1939). Frustration and Aggression. New Haven, CT: Yale University Press. https://doi.org/10.1037/10022-000

Faleti, S. A. (2006). Termination of Protracted Social Conflicts in Africa. In I. O. Albert (Ed.), Perspectives on Peace and Conflict in Africa. Ibadan: John Archers Ltd.

Feierabends, J. K., Feierabends, R., \& Nesvold, B. A. (1969). Social Changes and Political Violence: Cross National Pattern. In H. T. Graham, \& T. R. Gur (Eds.), History of Vi- 
olence in America (pp. 497-535). New York: Princeton.

Folarin, S. F. (2015). Types and Causes of Conflict (Chapter Three).

Galtung, J. (1971). A Structural Theory of Imperialism. Journal of Peace Research, 8, 81-117. https://doi.org/10.1177/002234337100800201

Garavoglia, M. (2013). European Union's Election Observation: The Case of ECOWAS Countries. Berlin: Institut für Europäische Politik e.V. (IEP).

https://nbn-resolving.org/urn:nbn:de:0168-ssoar-394184

Gberie, L., \& Addo, P. (2004). Challenges of Peace Implementation in Côte d'Ivoire. In Report on an Expert Workshop Presented by the Kofi Annan International Peacekeeping Training Centre (KAIPTC) in Collaboration with the Zentrum fur Internationale Friedenseinsatze (ZIF) (p. 84). Abidjan: Institute for Security Studies (ISS).

Harris, D. (2004). Post-Conflict Elections or Post-Elections Conflict: Sierra Leone 2002 and Patterns of Voting in Sub-Saharan Africa. Cadernos de Estudos Africanos, No. 5-6, 39-49. https://doi.org/10.4000/cea.1047

International Peace Institute [IPI] (2011). Elections and Stability in West Africa (p. 22). Meeting Note, New York: United Nations.

Konate, S. (2014). Trials of National Cohesion: Root Causes of Violence in Côte d'Ivoire. In E. Shizha (Ed.), Remapping Africa in the Global Space (pp. 29-42). Berlin: Springer. https://doi.org/10.1007/978-94-6209-836-7_3

Konate, S. A. (2004). The Politics of Identity and Violence in Côte d'Ivoire. West Africa Review, 5, 1-21.

Lenin, V. I. (1917). The State and Revolution: Marxist Theory of the State. Moscow: Progress Publishers.

Matlosa, K., Shale, V., \& Motsamai, D. (2009). Preventing and Managing Violent Election-Related Conflicts in Africa: Exploring Good Practices. In EISA Annual Symposium (p. 49). Johannesberg: Electoral Institute for Sustainable Democracy in Africa (ESIA).

Mayer, B. S. (2000). The Dynamics of Conflict Resolution: A Practitioner's Guide. San Francisco, CA: Jossey-Bass.

Nathan, L. (2000). The Four Horsement of the Apocalypse: The Structural Causes of Crisis and Violence. Peace and Change, 25, 188-207. https://doi.org/10.1111/0149-0508.00150

Oakland, K. (2005). Race and Racism.

Oberschall, A. (1978). Theories of Social Conflict. Annual Review of Sociology, 4, 291-315. https://doi.org/10.1146/annurev.so.04.080178.001451

Piccolino, G. (2011). David against Goliath in Côte d'Ivoire? Laurent Gbagbo's War against Global Governance. African Affairs, 111, 1-23. https://doi.org/10.1093/afraf/adr064

Ross, E. I. (1993). Write Now. New York: Barnes \& Noble Publishing.

Salehyan, I., \& Linebarger, C. (2013). Elections and Social Conflict in Africa. Climate Change and African Political Stability, Research Brief No. 6.

Sisk, T. D. (2008). Elections in Fragile States: Between Voice and Violence. In International Studies Association Annual Meeting Report (p. 24). California: The International Studies Association.

Straus, S. (2011). "It's Sheer Horror Here": Patterns of Violence during the First Four Months of Côte d'Ivoire's Post-Electoral Crisis. African Affairs, 110, 481-489.

https://doi.org/10.1093/afraf/adr024

United Nations to Côte d'Ivoire (2003). Côte d'Ivoire MINUCI Background. 
http://www.un.org/en/peacekeeping/missions/past/minuci/background.html

Utas, M., \& Christensen, M. M. (2016). The Gift of Violence: Ex-Militias and Ambiguous Debt Relations during Post-War Elections in Sierra Leone. African Conflict and Peace Building Review, 6, 23. https://doi.org/10.2979/africonfpeacrevi.6.2.02

Vogel, J. (1991). Culture, Politics, and National Identity in Côte d'lvoire. Social Research, $58,439-456$. 